GLOBAL JOURNAL OF EDUCATIONAL RESEARCH VOL 17, 2018: 9-13

COPYRIGHT@ BACHUDO SCIENCE CO. LTD PRINTED IN NIGERIA. ISSN 1596-6224

www.globaljournalseries.com; Info@globaljournalseries.com

\title{
TEACHING FOOD PRODUCTION AND PRESERVATION USING CONSTRUCTIVIST - BASED STRATEGY TO SS1 BIOLOGY STUDENTS FOR SELF-RELIANCE
}

\author{
E. E. EKON AND C. C. IHEJIAMAIZU
}

(Received 13, November 2017; Revision Accepted 5, February 2018)

\begin{abstract}
The world's population is growing everyday but the process of food production to meet the needs of the growing population is dwindling Consequently, conscientious efforts are being made towards improving teaching methods where students are actively involved in thinking and creating ideas themselves, guided by the teacher (rather than being spoon-fed) to acquire knowledge and skills towards improving crop yield and preservation of excesses. This paper identified 5 Es constructivist teaching model to be most appropriate. A sample lesson note for effective teaching of food production and preservation using 5Es constructivist model was developed as a guide. Researchers suggested that activity based strategies should be employed in teaching biology concepts to enhance acquisition of scientific knowledge and skills for student's self-reliance.
\end{abstract}

KEYWORDS: food production, food preservation Biology, 5Es constructivist model, self-reliance

\section{INTRODUCTION}

Food is one of the basic needs of man. It is defined as any nourishing substance that is eaten or drunk into the body to sustain life, provide energy and promote growth. Ramalingham (2013) opined that humans get food from both crops and livestock and growing crops is a more efficient way of producing food. Production of food, be it crops or livestock depend solely on acquisition of skills.

Onyemowo (2012) agreed with the above statement that production of food is wholly dependent upon someone having the practical knowledge necessary for plant cultivation, harvesting and making available for processors and consumers. On the otherhand, in a society that is full of waste, food preservation is an important process. Achufusi (2012) defined food preservation as a process of treating and handling food to stop or lower down spoilage, loss of quality, edibility or nutritional value and thus allow for longer storage. This simply allows food to undergo a change which increases its shelf live.

The world's population is growing every day but food production which is the basic necessity of life is dwindling. The past and recent administrations had been trying to launch several agricultural development programmes like Operation Feed the Nation (OFN) and the like, just to boost food production in the country but these yielded minimal results. The ultimate is to train the youths in our secondary schools to acquire these practical knowledge and skills early and practicalise them in future. After all one of the aims of science education as stated in the National Policy on Education (FRN, 2004) stressed that students are expected to acquire meaningful and relevant scientific knowledge in the classroom in order to apply same to everyday life matters so as to be self-reliant citizens of this great country.

It has been observed that the present

E. E. Ekon, Department of Science Education, University of Calabar, Calabar, Nigeria.

C. C. Ihejiamaizu, Department of Science Education, University of Calabar, Calabar, Nigeria.

(C) 2018 Bachudo Science Co. Ltd. This work is licensed under Creative Commons Attribution 4.0 International license. 
methods used in teaching Biology (conventional methods) in secondary schools do not augur well for the students to acquire meaningful knowledge of Biology contents and even apply the knowledge to solving individual and societal problems. Onwuka cited in Ekon (2013) added that teachers using the conventional method spoon-fed learners and so do not challenge them to discover new truths and new methods of tackling problems for themselves and the society as a whole. Mandor (2002) posited that the conventional methods of teaching Biology have contributed a great deal to the extreme difficulty in achieving the aims and objectives of Science Education in general and Biology in particular. The researcher further emphasized that learners should be allowed to actively take part in science lessons and not be allowed to be passive listeners.

This therefore calls for a better teaching method that could help students be actively involved in class lessons in order to gain better understanding, experience and scientific knowledge. In recent, innovative teaching strategies advocated for effective learning and teaching of science include corporative learning, problem solving, inquiry based learning, constructivist method and others (Nwosu \& Nzewi 1998).

Constructivism is a teaching strategy which holds the view that scientific knowledge is personally constructed by the learner based on his experiences (Mandor, 2002) Nworgu (2006) opined that constructivism is a learning strategy that emphasizes that learners be actively involved in the process of learning. In a constructivists' classroom, students redefine, elaborate and change their initial conception through interaction among themselves and their own environment (Nwosu, 2003), Ekon (2013) added that teachers in constructivists' classrooms are expected to interact with students, create interesting activities for every learner to participate. Teachers are also expected to avoid direct instruction but attempt to lead the students through question techniques and activities to discover, discuss and verbalize new scientific knowledge.

Constructivism is therefore, dynamic interactive and problem solving oriented. It also gives opportunity to learners to explore their environment and work in groups. This is in line with Brunner's and Piaget's theories on learning. Both propounded that learning should be an active process giving learners the opportunity to construct new ideas based on discovery or experience. There are many constructivists' models but this paper is interested in the 5Es model which involves five stages namely engagement, exploration explanation, elaboration and evaluation.

\section{Empirical studies on effects of constructivist instructional model}

Aham (2012) investigated the effect of constructivist instructional approach on students' achievement and interest in genetics in Enugu education zone. The study adopted quasi experimental design, 200 SSII students were randomly selected from four schools that were purposively selected from the education zone. Mean and standard deviation were used to answer research questions and analysis of variance (ANOVA) to test for the hypotheses. The result revealed that the constructivist instructional approach was more effective than the lecture method in facilitating students' achievement and interest in genetics.

Mandor (2002) examined the effect of constructivist based instructional model on acquisition of Science Process Skills among Junior Secondary School students. The study was carried out in Calabar municipality and adopted a non-equivalent pretest and posttest quasi experimental design. Percentage mean and standard deviation were used to answer research questions and while analysis of covariance (ANCOVA) was used to test the hypotheses. The study revealed that constructivist based model enhanced students' acquisition of science process skills better than the conventional method.

From the literature reviewed, researchers have shown that constructivist based instructional models or strategies are better options in achieving the desired learning outcome in students, boosting their interest in science subject this helping them in acquiring scientific skills. This by implication has the intention of accelerating achievement and eradicating poverty.

The purpose of this study therefore is to throw more light on the use of this innovative strategy to help improve the teaching and learning of biology in enhancing students' participatory roles in the classroom setting so as to encourage the acquisition of scientific knowledge. 


\section{A sample lesson note for teaching food production and preservation using the 5Es constructivist based strategy:}

Date:

Class:

SS1

Duration:

Topic:

40 mins $\times 3$

Food production and preservation

Specific objective: At the end of the lesson, students should be able to

a). Mention the methods of food production in their locality

b). State reasons why preservation of food is needed

c). Outline the methods of preserving food items

Entry behaviour: The students had known that every living thing requires food for growth and repair of body cells.

Instructional materials: Charts, pictures and assorted fresh foods and their processed counterparts e.g. fresh and canned fruits or vegetables, apples grapes etc.

Entry behaviour test: How do you feel when you stay away from food for $8 \mathrm{hrs}$ ?

\section{INSTRUCTIONAL PROCEDURES}

Stage 1: Invitation/Engagement

The teacher asks the students the following questions to engage them in thinking (to arouse their thinking abilities.

(1) Why do you eat food?

(2) What quantity of food would be enough to feed all the students in this class for one week?

How may we produce enough food for all the students and prevent wastage?

The teacher gives the students the opportunity to attempt the question and at the same time guides the students in answering those questions and introduces the topic: food production and preservation. While trying to introduce the lesson, the teacher relates the previous lesson to the new one.

\section{Stage 2: Exploration}

The students are divided into heterogeneous groups ensuring that every student performs the task given in their group.
Pictures of well-fed children and malnourished ones are given to them to discuss.

The teacher guides them by giving them instructions like the following:

1. What are the health conditions of those children in the pictures

2. What are the causes of malnutrition?

3. What can be done to improve food production in your locality to avoid malnutrition?

4. When these foods are produced in large quantities, is there any possibility of wasting the food?

5. How then can the left over or unused food materials be preserved?

The teacher guides the students in their discussion and should not allow it to be boring, but encourages them to become active in their different groups. Answers, ideas and suggestions are written down for class discussion.

\section{Stage 3: Explanation}

The students come together and discuss their activities and possible answers to the questions asked and other questions that may had arisen in the course of their discussion. The teacher explains further based on their contributions the malnourishment in our society is as a result of "no sufficient food" for everybody", therefore there is a need for food to be produce in large quantities for it to be enough for everybody. What can you do to produce food?

Food come from plants mainly, which means that plants are the main sources of food. In a situation where plants are attacked by pests, diseases, drought, war and climatic factors those plants would not grow well but will die or be stunted and there will certainly be food shortage. The teacher can go further to show the students some pictures and charts of pests like insects (locust, grasshoppers, caterpillar), rodents (rats, rabbits, squirrels). Plants suffering from diseases like leads pot mosaic, blight, WTH etc. The teacher may ask the students if plants are attacked by pests, rodents and diseases, whether they can produce enough food as compared to when they are not attacked.

To avoid these attack, what do you think can be done?

The teacher gives them opportunities to respond and followed up with the charts of preventive measures or control of pest and diseases. 
Apart from attacks, if the soil fertility is improved, plants will tend to produce more food. So how can the soil fertility be improved? The teacher gives students opportunities to brainstorm and answer before presenting some examples of in-organic and organic manures to the students and explain further that soil fertility can be improved through the use of inorganic and organic fertilizers. Organic fertilizers may be gotten from compost; other manures from vegetable waste can be added to improve the nutrient in the soil, while in-organic fertilizers are bagged for sale.

Food production can also be improved through the following methods

(a) Utilizing better techniques for crop cultivation like crop rotation, preventing soil erosion

(b) observing proper timing for planting

(c) Using good varieties of crops that may grow well and yield earlier than some other ones.

(d) Application of hybridized crops where some better seedling are crossed to improve qualities of seeds as in citrus

(e) Disease resistant varieties of crops could also be cultivated to increase food yield

(f) Tillage is necessary for crop cultivation

(g) Weeds control: weeds compete with crops for food, so to maintain a good yield, a control of weeds growth is necessary

\section{Different methods of preserving food}

Preservation of food is the act of preserving food from getting spoilt or wasting them. Preservation is only possible when the favourable condition(s) for breeding microbes bacteria fungi, yeast etc is totally removed or eradicated from the preserved food item. That is to say if the metabolic reactions of microbes causing spoilage could be slowed down or removed altogether in the food item. Furthermore, Wikipedia encyclopaedia cited in Achufusi has it that maintaining nutritional value, texture and flavour is an important aspect of food preservation.

Therefore the teacher presents some food items to the students and ask the students to brainstorm on possible methods that could be used to preserved them in their locality. Methods of preservation according to Ramalingham (2013) include

$\begin{array}{ll}- & \text { Bagging } \\ - & \text { Drying/smoking } \\ - & \text { Refrigerating or freezing } \\ - & \text { Salting } \\ - & \text { Coating with sugar or honey } \\ - & \text { Barning } \\ - & \text { Bottling and canning } \\ - & \text { Fermentation } \\ - & \text { Irradiation } \\ - & \text { Pasteurization }\end{array}$

\section{Stage 4: Elaboration}

Students are given opportunities to acquire new knowledge by applying what they had discussed to other situations probably outside the classroom. The teacher guides their through the stages of learning by asking questions like.

1. Mention three food items in your locality that could be preserved using the above named methods

2. Why do salting or smoking mostly used to preserve fresh fish

3. Why use honey as preservative agent.

\section{Stage 4: Evaluation}

The teacher gives students opportunity to ask questions and allow other students in the same class to attempt answering such questions before the teacher concludes. The teacher asks the following questions to ascertain their level of understanding of the lesson

1. Mention 3 methods that could be used in your locality to increase food production.

2. State five reasons why preservation is necessary

3. List 2 causative agents of food spoilage 
4. Draw an arrow from the under listed food items to match the correct preservation method

\author{
Yam \\ Rice \\ Beans \\ Fresh fish \\ Friesh prawn \\ Pumpkin leaves \\ Water leaf \\ Tomatoes
}

\author{
Jellying \\ Canning \\ Barning \\ Drying \\ Salting \\ Bagging
}

\section{CONCLUSION}

For the students to gain from the study of Biology, students should be actively involved in classroom activities and extend the knowledge acquired in the classroom to the larger society. By so doing, students would become self-reliant after graduation when the scientific skills are implemented in the society. Such would become an employer of labour.

\section{REFERENCES}

Achufusi, J. N., 2012. The use of Active learning process (ALP) in the teaching of methods of preserving and storing food. Science teachers association of Nigeria; Biology Panel series; 1-16.

Attah, A. C., 2013. Effect of constructivist instructional approach on students' achievement and interest in Genetics in Enugu Education zone of Enugu state. On unpublished M.Ed thesis University of Nigeria, Nsukka.

Ekon, E. E., 2013. Effect of five step conceptual change instructional model on students' perception of their psychosocial learning environment, cognitive achievement and interest in biology. An unpublished Ph.D Thesis. Faculty of education university of Nigeria. Nsukka.
Federal Republic of Nigeria., 2004. National policy on Education. $4^{\text {th }}(\mathrm{ed})$, Lagos: Nigerian educational research and development council press.

Mandor, A. K., 2002. Effects of constructivist models on acquisition of science process skill among junior secondary school, students. On unpublished M.Ed thesis University of Nigeria, Nsukka.

Nworgu, B. G., 2006. Educational research basic issues and methodology $\left(2^{\text {nd }} e d\right)$ Enugu: university Trust publishers.

Nwosu, A. A and Nzewi, U. M., 1998. Using constructivist model in communication science. Proceedings of the $39^{\text {th }}$ Annual Conference of Science Teachers Association of Nigeria, 349-353.

Onyemowo, A. F., 2012. Teaching relevance of biology to food production, wastage, preservation and storage using demonstration teaching strategy. STAN: Biology Panel, 86-89.

Ramalingam, S. T., 2013. Modern biology for senior secondary schools. $\left(6^{\text {th }}\right.$ ed $)$. Onitsha: Africana First publishers plc. 